\title{
ERAM OS CRIATIVOS PUBLICITÁRIOS ARTISTAS? IDENTIDADE, COTIDIANO E DISCURSO.
}

\author{
Were the advertising creatives artists? \\ Identity, quotidian, discourse.
}

\section{Fueron los creativos publicitarios artistas?}

Identidad, cotidiano, discurso.

Maria Cristina Dias Alves ${ }^{1}$

\section{Resumo}

Este trabalho aborda alguns conceitos de cotidianidade, identidade e a produção de sentidos no interior trabalho dos criativos publicitários face à imprevisibilidade de interação com um consumidor cada vez mais disperso, produtor e propagador de narrativas. Objetivamos discutir a identidade do profissional de criação publicitária como um construto, a partir da aproximação do fazer artístico, que tem sido alterada na atualidade, momento de transição em que papéis e normatizações estão sendo revistos.

Palavras-chave: criação publicitária, cotidiano, identidade, discurso.

\begin{abstract}
This paper treats some concepts of quotidianity, identity and of the production of meaning within the creative advertising work due of an unpredictably interaction with increasingly consumers dispersed, producers and propagators of stories. Our objective is to discuss the identity of the professional advertising creation as a construct, from the modes of art making, which been changing in contemporaneity, time of transition, in which roles and norms are being revised.
\end{abstract}

Keywords: advertising creation, quotidian, identity, discourse.

\section{Resumen}

\footnotetext{
${ }^{1}$ Doutoranda em Ciências da Comunicação da Escola de Comunicações e Artes da Universidade de São Paulo, professora conferencista da disciplina Redação 1, graduação em Publicidade e Propaganda na ECA-USP; diretora de criação e redatora publicitária. E-mail: crisdias@ usp.br.
} 
Eram os criativos publicitários artistas? Identidade, cotidiano e discurso.

de Maria Cristina Dias Alves

En este artículo analizamos algunos conceptos acerca de la cotidianidad, la identidad y la producción del sentido en el interior de el trabajo de creativo de la publicidad debido a la imprevisibilidad de la interacción con consumidores cada vez más dispersos, productores y propagadores del narrativas. Nuestro objetivo es discutir la identidad del la creación profesional de la publicidad como una construcción, desde el enfoque de hacer arte, que se ha cambiante en la actualidad, momento de transición en el que los roles y las normas están siendo revisadas.

Palabras-clave: creación de la publicidad, cotidiano, identidad, discurso.

\section{INTRODUÇÃO}

Interregno: a antiga maneira de agir já não funciona mais e novas maneiras ainda não foram inventadas. Zigmunt Bauman $^{2}$

Este artigo é parte do nosso projeto de doutorado, em fase inicial, no qual investigaremos o fazer do criativo publicitário na atualidade e a imprevisibilidade da circulação de sentidos face a um consumidor produtor e propagador de narrativas na rede online.

O caminho que procuramos percorrer nesse momento aproxima-se da cotidianidade e sua indissociabilidade das relações de produção (HELLER, 2008, GOFFMAN, 1985) e alguns dos discursos que permeiam essas relações.

Levamos em conta as identidades sociais construídas no interior das representações (HALL, 1997) e o modo pelo qual as mudanças ocasionadas pela inserção das tecnologias de informação e comunicação têm modificado procedimentos e o olhar do criativo sobre o seu próprio trabalho.

A pesquisa encontra-se em fase inicial, portanto, momento de leituras, reflexões. Ainda estamos percorrendo os caminhos que irão conformar a metodologia da pesquisa e, principalmente, o recorte do objeto de estudo. O que nos inquieta é a possibilidade de ouvir, olhar e assim nos aproximar do universo da criação

\footnotetext{
${ }^{2}$ Entrevista disponível em: <http://www.videolog.tv/video.php?id=791710>. Acesso ago. 2012
} 
Eram os criativos publicitários artistas? Identidade, cotidiano e discurso.

de Maria Cristina Dias Alves

publicitária, no cotidiano dos criativos $^{3}$ e suas idiossincrasias, a fim de compreender processos de trabalho, um "saber fazer" que se reinventa a cada dia.

A maioria dos estudos sobre publicidade, desde a análise semiótica de Barthes (SANTARELLI, 2009: 13), recaem sobre o produto final, seja um anúncio, um comercial entre outras peças e, muitos poucos, como os de Rocha (1985) e Bertomeu (2008), se voltam para "esse fazer" da publicidade por meio da observação de métodos de trabalho, mais do que a análise de estratégias discursivas.

Essa inquietação partiu da própria experiência da autora, que trabalha há anos em agências como redatora e diretora de criação, e pode ver, ouvir, sentir, enfim, ser parte desse cotidiano e vivenciar mudanças operacionais, de metodologias de trabalho, bem como no foco de campanhas.

Sabemos que um objeto de estudo existe porque um sujeito o observa sob um recorte específico. O olhar desse sujeito sobre o objeto é singular, uma construção do pesquisador que resulta em um texto no qual o autor é um "indivíduosujeito resultado dos discursos sociais, com um sistema de referências (por ela) interpelado, a qual interage com a realidade apropriando-se dela de acordo com seus valores" (BACCEGA, 2006: 6).

Por isso, nos interessa certo distanciamento da experiência para que possamos enxergar pelo olhar do outro, como condição de validade da pesquisa

\begin{abstract}
[...] propomos que a objetividade seja fundada no comportamento do outro, ou ainda, para logo revelar o aspecto paradoxal de nosso pensamento, pretendemos escolher o olho do outro - sempre o olho do outro - para ver a forma - a forma felizmente abstrata - do fenômeno objetivo: Dize-me o que vês e eu te direi o que é. Só esse circuito, na aparência, insensato, pode nos dar alguma garantia de que dizemos completa abstração de nossas ideias primeiras. Ah! não há dúvida de que sabemos que vamos perder![...] Precisávamos tanto estar de modo integral em nossa visão de mundo! Mas é exatamente essa necessidade que precisa ser superada. Vamos! não é a clara luz, é a beira da sombra que o raio, ao difratar-se, entrega-nos seus segredos (BACCHELARD, 1996: 295).
\end{abstract}

Esse olhar do outro só será possível quando, depois da pesquisa bibliográfica, formos a campo para confrontar ou confirmar uma das nossas hipóteses sobre as mudanças de procedimentos de trabalho e no modelo de agência de publicidade como as conhecemos até agora.

\footnotetext{
${ }^{3}$ Utilizamos a palavra criativos, bem como redator (a) e diretor (a) de arte, para nos referirmos aos profissionais que criam campanhas em agências de publicidade, sem distinção de gênero.
} 
Eram os criativos publicitários artistas? Identidade, cotidiano e discurso.

de Maria Cristina Dias Alves

\section{PUBLICIDADE, MODOS DE FAZER.}

Desde o início do século passado, com o desenvolvimento da sociedade industrial (e das cidades), a publicidade ${ }^{4}$ foi uma das principais responsáveis pelo incremento da produção de bens e serviços.

A prática publicitária foi aprendida juntamente com o aprendizado consumidor, e os criativos, profissionais advindos de outras áreas, como $\mathrm{o}$ jornalismo, as artes e a literatura, colocavam o seu talento e conhecimento a serviço da divulgação dos novos bens produzidos em massa. Pintores, como Toulouse Lautrec e Mucha, emprestaram os traços e as cores da sua arte para os cartazes publicitários com as representações da sociedade moderna que se conformava.

No Brasil, muitos poetas eram requisitados por anunciantes para criar peças publicitárias. Casimiro de Abreu foi um dos primeiros a fazer anúncios e também Olavo Bilac, Emílio de Menezes, Basílio Viana e, mais tarde, poetas da nossa música, como Noel Rosa (CARRASCOZA, 2003: 65-71).

Para Marcondes (2001, p.19), a chegada da General Motors, em 1915, foi importante para a profissionalização da propaganda no Brasil, com seu departamento de propaganda e técnicas oriundas matriz norte-americana. Contudo, segundo o autor, ainda não dialogavam com a nossa cultura, o que só vem a ocorrer em 1960/1970, resultado do trabalho de algumas agências e de profissionais de criação.

Até 1951, quando foi criada a primeira escola de propaganda (GRACIOSO, PENTEADO, 2001), os criativos das agências não eram publicitários de origem. A profissão de publicitário surgiu somente na década de 1970:

Trata-se de uma carreira profissional criada em 1970 e implantada nos anos seguintes. Por usa natureza híbrida - enraizada nas comunicações e nas artes - e seu perfil multifacetado - oscilante entre a ciência, a tecnologia e a filosofia - suscita perplexidades, inspirando reticências (MARQUES DE MELO, 2010: 55).

Uma carreira considerada recente e que, no Brasil, teve seu auge na década de 1970 e nas seguintes, quando os profissionais brasileiros conquistaram visibilidade

\footnotetext{
${ }^{4}$ Segundo Barbosa, a publicidade está inserida no contexto do marketing, que visa o convencimento, a persuasão e envolvimento para satisfazer necessidades por meio de um produto ou serviço (BARBOSA, 1995: 31-34). Desse modo, utilizamos o termo publicidade, já que estamos nos referirmos ao sistema publicitário.
} 
Eram os criativos publicitários artistas? Identidade, cotidiano e discurso.

de Maria Cristina Dias Alves

internacional, premiados em festivais e, principalmente, obtendo resultados significativos de vendas.

Por estar relacionada à venda de produtos e serviços, a publicidade (e também os publicitários) tem sido objeto de crítica por suas estratégias persuasivas e de estímulo ao consumo. Contudo, o consumo faz parte do sistema social e deve ser compreendido como tal, atribuindo sentido aos objetos.

[...] É no consumo que homens e objetos se olham de frente, se nomeiam e se definem de maneira recíproca. A constante determinação dos valores de uso faz de um tipo de produto genérico uma idiossincrasia. Da construção, o lar. Do vinho, a cerimônia. Da roupa, a identidade. Da comida, a refeição. Um processo social permanente de seres humanos definindo-se num espelho de objetos e a estes num espelho de homens [...] (ROCHA, 1985: 68).

De acordo com Frederico (2008: 87), o extenso caminho entre a produção e o consumo é encurtado pela publicidade, que "apressa" a realização do valor de troca da mercadoria, como parte do sistema de circulação e, por isso mesmo, não pode ser dissociada da produção.

Para Baudrillard, a publicidade é antes consumida do que criada para conduzir o consumo, seu excesso já foi associado à abundância e à liberdade em pesquisa realizada na Alemanha Oriental: "a publicidade desempenha essa função fútil, regressiva, inessencial, mas, com isso, tanto mais profundamente exigida" (BAUDRILLARD, 1993: 182, 183).

Um mito contemporâneo, fala escolhida pela história e definida pela intenção e a maneira pela qual é proferida. Fala do uso social do objeto acrescentado à sua matéria, como escreve Barthes (1978) e que, como a mitologia, não concorda com o que o mundo é, mas sim, com aquilo que o mundo quer ser.

A capacidade de sedução e a criatividade das campanhas fizeram com que a grande maioria dos estudos sobre publicidade recaísse em análises do produto final do trabalho dos publicitários, como escrevemos, e alguns, poucos, no fazer desse profissional, que reinventou procedimentos cada vez que um novo meio surgia ou que as novas exigências do mercado apareciam.

O trabalho do publicitário se assemelha a muitos outros da sociedade capitalista, uma vez que entra em uma "cadeia produtiva" que tem início na 
Eram os criativos publicitários artistas? Identidade, cotidiano e discurso.

de Maria Cristina Dias Alves

solicitação de determinado $j o b^{5}$ por um cliente - atendimento, planejamento, criação, produção, mídia - e mesmo antes desse processo, na conquista do cliente pela agência, um extenso trabalho também de persuasão e de convencimento que envolve todos os departamentos.

A ideia de que somente esses profissionais são os "criativos" das agências tem relação com o tipo de trabalho que executam, de produzir narrativas e imagens sedutoras e persuasivas que embalem produtos e serviços. É o ato de criação das peças da campanha, ainda que materializado pelas mãos de outros profissionais/fornecedores de serviços. Contudo, os publicitários responsáveis pela criação das campanhas têm metas a cumprir

[...] a resposta em resultados efetivos na divulgação da marca de cada bem ou serviço anunciado, em resultados na geração ou fixação de impulsos de compra e em resultados efetivos no fluxo então gerado de receita e capital (pelas vendas objetivas conseguidas) passa a ser o metro e a medida da boa publicidade - e, por extensão, já que deixar de obter sucesso se assemelha a negligenciar o dever, como prega o sistema capitalista, igualmente metro e medida da capacitação profissional de quem a executa (PIRATININGA, 1985: 22).

O desafio de estabelecer um diferencial para um produto ou serviço (quando não intrínseco a estes) só pode se vendido através da criatividade artística, dialética que, segundo o autor, se torna possível por meio do conteúdo estético manifestado na "arte publicitária" que sensibiliza, emociona.

Por isso, a denominação "criativo", profissional que, além da formação em publicidade e propaganda, precisa estar atualizado nas diferentes esferas das artes, como o cinema, a literatura, a pintura. E ainda, o jornalismo, as ficções televisivas e, principalmente, na vida cotidiana tão permeada por outros tantos discursos, muitos advindos dos novos suportes midiáticos.

Ao entrevistar publicitários, Rocha relata um fazer publicitário que envolve muitos campos do saber, motivo pelo qual os profissionais se autonomearam conhecedores de "cultura geral" e, como acontece com o bricoleur de Lévi-Strauss, reúnem pedaços aglomerados a espera do momento de ser usados.

Seu ponto de partida e sua operação lógica é agregar todos os fragmentos de saber disponíveis e reuni-los na elaboração de um instrumental. É nesse sentido que podemos relacionar publicidade e bricolagem [...] $O$ publicitário recebe um instrumental

\footnotetext{
5 Terminologia comumente utilizada em agências de publicidade para se referir a um Pedido Interno de Trabalho - PIT.
} 
Eram os criativos publicitários artistas? Identidade, cotidiano e discurso.

de Maria Cristina Dias Alves

dado de fora pelos saberes já construídos na nossa sociedade (ROCHA, 1985: 54).

Uma das principais exigências em relação a esses profissionais é possuir um amplo repertório cultural, inclusive do universo no qual se insere o público para o qual são criadas as peças publicitárias

$\mathrm{Na}$ atualidade, contudo, há dificuldade de recorte desse público - um consumidor cada vez mais disperso, fragmentado - que tem escapado às segmentações, como se refere Canevacci à morte do target: agora, mais do que nunca, o consumidor é co-criador, em busca de auto-representação, porque, segundo ele, ninguém mais quer ser representado. ${ }^{6}$

A aproximação do trabalho do criativo publicitário da arte também parece decorrer do perfil do criativo publicitário no início do século passado - a maioria artistas plásticos e gráficos, escritores e poetas - o que veio sedimentar essa correlação associada ao tipo de atividade.

Para Casaqui (2011), a expressão da criatividade e a aura associada às atividades dos profissionais que concebem as campanhas, "contrasta com a dinâmica do campo, tensionada pelos anunciantes e pelos objetivos de resultados mensuráveis".

Como nos lembra Santos, o poético deve comparecer, mas sempre em função de uma estratégia de comunicação que privilegie os objetivos da campanha: "Mais precisamente, a arte deve estar a serviço da intencionalidade de marketing, deve ter uma funcionalidade, um objetivo de venda (SANTOS, 2009: 36).

Atemos-nos aqui não apenas a intencionalidade do trabalho dos profissionais de criação, bem como à cotidianidade, na qual todos estão imersos, uma vez que

[...] a vida cotidiana é a vida do homem inteiro; ou seja, o homem participa na vida cotidiana com todos os aspectos de sua individualidade, de sua personalidade. Nela, colocam se "em funcionamento" todos os seus sentidos, todas as suas capacidades intelectuais, suas habilidades manipulativas seus sentimentos, paixões, ideias, ideologias. $O$ fato que todas as suas capacidades se coloquem em funcionamento determina também, naturalmente que nenhuma delas possa realizar-se, nem de longe, em toda sua intensidade. O homem da cotidianidade é atuante e fruidor, ativo e receptivo, mas não tem nem tempo nem possibilidade de se absorver inteiramente em nenhum desses aspectos; por isso, não pode aguçá-los em toda sua intensidade (HELLER, 2008: 32).

Nos processos de trabalho de criação, a subjetividade de cada profissional não é

\footnotetext{
${ }^{6}$ Tema discutido por Massimo Canevacci durante a abertura do III Pró-Pesq, evento realizado na Escola de Comunicações e Artes da Universidade de São Paulo, nos dias 24 e 25 de maio de 2012.
} 
Eram os criativos publicitários artistas? Identidade, cotidiano e discurso.

de Maria Cristina Dias Alves

separada do fazer e esse criativo, produtor de narrativas, também é receptor de tantas outras, inclusive àquelas produzidas pelos próprios consumidores a partir de seu trabalho.

Como escreve Trindade (2008: 75,76), as questões da recepção passam por códigos culturais que se "naturalizam" na práxis cultural. A recepção se dá em processos de produção de sentido, que interferem nos processos de leitura e interpretação de códigos complexos.

Se há ressignificação de narrativas publicitárias pelos consumidores, também o fazem os publicitários, que são consumidores de produtos e serviços cujas marcas permeiam o seu cotidiano.

\section{IDENTIDADE, REPRESENTAÇÃO E TRABALHO.}

A comunicação tem um papel central na relação do homem com a sua atividade, contribuindo para a compreensão do mundo do trabalho. Contrariando o senso comum, é o trabalho que deve se adaptar ao homem e não o inverso (DURAFFOURG, 2007: 82).

Entendemos as nomeações de processos de trabalho, cujos sentidos orientam processos em empresas, bem como as denominações dos coletivos, tais como equipe, time ou mesmo família, como estratégias discursivas que buscam homogeneizar procedimentos.

Em uma agência de publicidade, podemos situar as próprias denominações dos departamentos como um sistema de classificação de procedimentos: atender o cliente, planejar, criar a campanha, produzir e contratar os veículos para a divulgação dos materiais etc. Classificações que sedimentam papéis no interior do processo de trabalho e que acabam por definir o que e quem pode executar determinada tarefa e, ainda, restringem a abrangência do trabalho de cada departamento.

Se há cada vez mais interseções entre o atendimento e o planejamento, entre a mídia e a criação, estas trazem mudanças no modo formatar um briefing para a criação, por exemplo, levando em conta não apenas as necessidades urgentes do cliente, mas também as possibilidades de extensão de uma peça criativa para diversos meios e plataformas, o que implica um plano de mídia também criativo.

Para Barbosa e Trindade (2007), existem seis níveis de enunciação na publicidade: anunciante; marketing do anunciante; comunicação integrada do 
Eram os criativos publicitários artistas? Identidade, cotidiano e discurso.

de Maria Cristina Dias Alves

anunciante; publicidade e propaganda - agência, atendimento, planejamento, mídia, criação - codificação; produção das peças dacampanha (terceirizado/técnico de cada produto midiático) e veiculação (diferentes suportes/canais que transmitem as mensagens da campanha aos receptores).

Os três primeiros níveis da enunciação da emissão (agência, produção e veiculação) guardam relações de interferência mais diretas com os enunciados das campanhas, o que nos faz atentar para o fato da materialidade das peças publicitárias de uma campanha nos diferentes níveis de enunciação na emissão/produção/veiculação demandam considerar as especificidades dos suportes que inscrevem tais mensagens, bem como os distintos sujeitos que interferem mútua e dinamicamente nesses níveis de enunciação" (BARBOSA; TRINDADE, 2007: 68)

Para compreender essa dinâmica, lembramos que o modelo de trabalho de uma agência ainda segue o organograma implementado na década de 1970, com poucas alterações, eventualmente, trio de dois redatores e um diretor de arte ou vice-versa (CARRASCOZA, 2011: 15).

Se até a década de 1990 esses profissionais ainda eram considerados "artistas", na atualidade o perfil dos criativos parece estar em processo de mudança, tanto pelas modificações trazidas pela inserção de tecnologias no "modo de fazer" como pela emergência de novos suportes midiáticos por onde as mensagens circulam.

Disso decorre o fato de que, na atualidade, os profissionais de criação serem chamados para participar mais ativamente do negócio como um todo e não apenas da criação de campanhas. O que resulta em mudanças de processos de trabalho, como também na "imagem" que os criativos fazem de si mesmos.

Em recente teste piloto (ALVES, 2012) identificamos algumas dessas mudanças na voz dos próprios criativos, que acreditam estar perdendo espaço para o planejamento, considerado "a nova criação" das agências.

Ao se referir às identidades, construídas no interior de representações, Hall (1997) salienta ser consequência de um processo de identificação o qual "permite que nos posicionemos no interior das definições que os discursos culturais (exteriores) fornecem ou que nos subjetivemos (dentro deles)."

$\mathrm{Na}$ formação de subjetividades no interior da cultura, salienta o autor, a “estratégia é alinhar as motivações e aspirações pessoais e subjetivas de cada sujeito às motivações da organização, redefinir suas habilidades e capacidades conforme as especificações pessoais e profissionais da empresa, internalizar objetivos organizacionais como suas próprias metas" (HALL, 1997). 
Eram os criativos publicitários artistas? Identidade, cotidiano e discurso.

de Maria Cristina Dias Alves

Wittgenstein também é lembrado pelo autor em relação ao significado surgido dos jogos de linguagem e dos sistemas de classificações nos quais as coisas estão inseridas para concluir que, mesmo havendo algo além do discurso, toda prática tem seu caráter discursivo. Ele utiliza o termo identidade como uma posição assumida obrigatoriamente pelo sujeito, ou seja, uma representação construída "longo de uma falta, de uma divisão, a partir do lugar do outro" (HALL, WOODWARD, 2000: 112).

Para compreender o que significa essa representação, recorremos a Goffman, que a define como "toda atividade de um indivíduo que se passa num período caracterizado por sua presença contínua diante de um grupo particular de observadores e que tem sobre estes alguma influência” (1985: 29). Na representação há o indivíduo como personagem, que é um efeito dramático, e o indivíduo como ator, com atributos de natureza psicológica, definições que relacionamos com o discursivo e o psíquico de que trata Hall, em cuja sutura se constitui identidade.

Para Goffman, a representação serve para expressar principalmente as características da tarefa que é representada e não as do ator e, portanto,

[...] um grupo de indivíduos que poderiam ser desiguais sob diferentes aspectos e, por isso, desejosos de manter distâncias sociais uns dos outros, descobrem que estão numa relação de familiaridade forçada, característica dos companheiros de equipe empenhados em encenar uma representação [...] (GOFFMAN, 1985: 82)

Essa "familiaridade forçada" de profissionais da agência fica mais evidente quanto olhamos para as duplas (ou trios) de criação e suas relações diárias nas quais é necessário que a "química" funcione.

Ao criar um anúncio, por exemplo, o redator pode ter em mente imagens, cores e tipologias que dialogam com seu título e texto, o que não quer dizer que seja o layout idealizado pelo diretor de arte. E vice-versa. De modo que, por meio do diálogo e de concessões, encontram um "caminho do meio", que possa atender primeiramente às exigências do briefing e à expressão dos criativos, tendo como mediador o diretor de criação, que também contribui ou interfere no produto final a ser apresentado ao cliente.

São relações de forças que fazem parte do próprio processo criativo, positiva ou negativamente, ainda mais quando há concorrência interna entre as equipes de criação, ou seja, quando um mesmo job é dado para diferentes profissionais com o objetivo de estimular a competição e, assim, possibilitar uma variedade de 
Eram os criativos publicitários artistas? Identidade, cotidiano e discurso.

de Maria Cristina Dias Alves

caminhos criativos.

Outro fator que tem modificado os processos de criação das campanhas referese à emergência do planejamento criativo nas agências (até bem pouco tempo denominado estratégico). Este, baseado em pesquisas qualitativas sobre consumidores e mercados, norteia o posicionamento do produto e da marca e, muitas vezes, determina o percurso criativo por meio de um conceito já definido para as campanhas. Muitas vezes advém do próprio cliente o conceito, seja por um alinhamento internacional da marca ou por estratégias de mercado pontuais.

Para Carreira, é no departamento de marketing que nasce o posicionamento do produto que, “[...] sob a perspectiva da circulação de significado, permite pensar a mercadoria e sua marca como um texto que comunica algo e que faz algum sentido para quem a compra" (2007: 106, 107).

Novos procedimentos emergiram paulatinamente a partir da década de 1980, com a consolidação do profissional de publicidade, de marketing e, recentemente de o de "novas mídias", com especializações cada vez mais estratificadas, como acontece nos demais sistemas de produção.

O mundo social em que vivemos nos converte a todos em fragmentos de pessoas com vínculos, habilidades e capacidades particulares, integrados às estruturas dinâmicas e potentes que damos o nome de "modo de produção". Nossa "posicionalidade" ou "situacionalidade" com relação a isso é uma construção social exatamente da mesma maneira como o modo de produção é uma criação social. Essa "posicionalidade" define quem ou o que somos (ao menos nesse momento). E a "posição a partir da qual vemos" no âmbito desse processo proporciona boa parte do material de que se ocupa nossa consciência e nosso imaginário (HARVEY, 2004: 310).

A pressão pela qual passam esses profissionais e os embates entre departamentos se tornou uma marca recorrente em muitas mensagens dispersas em blogs, sites e páginas que abordam o cotidiano dos publicitários, sedimentando ainda mais estereótipos. 
Fig. 1

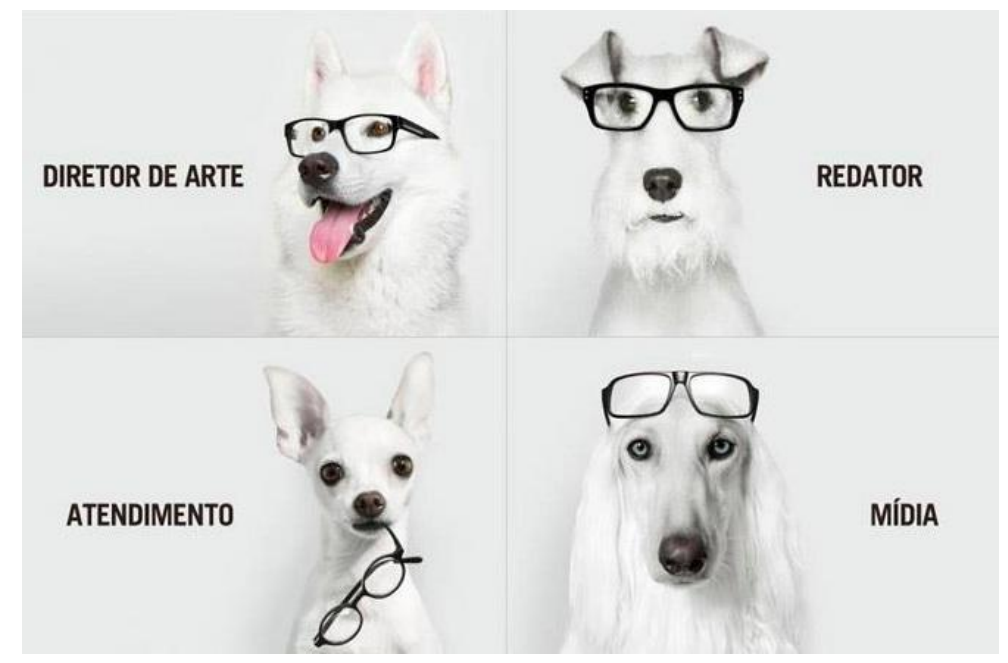

\section{DESENCANTAMENTO, REENCANTAMENTO.}

Há certo desencantamento com o trabalho do criativo, que, ao nosso ver, parece ser uma característica da sociedade contemporânea, de excessos, na qual a fragmentação das identidades dissolve certezas.

O "desencantamento do mundo" é um processo que atravessa os tempos modernos. Não se realiza plenamente. Desenvolve-se, reitera-se, diversifica-se e continua. Não termina nunca, envolvendo a filosofia, as ciências e as artes, tanto quanto os modos de ser, pensar, sentir, agir, imaginar e fabular. Traduz-se em formas de sociabilidade, modos de organizar o trabalho e a produção, relações, processos e estruturas de dominação e apropriação, alienação e emancipação. Implica a superação de tradições, superstições e religiões no que se refere aos diferentes setores do espaço público (IANNI, 2003: 263).

Em nossa experiência recente nas turmas de Publicidade e Propaganda da Escola de Comunicações e Artes da Universidade de São Paulo, podemos perceber a forte tendência dos estudantes do $3^{\circ}$ e do $4^{\circ}$ ano para a área de planejamento e atendimento e, muito poucos, interessados pela criação.

Já Casaqui, em pesquisa com estudantes de publicidade de diversas instituições do país, sintetiza expectativas e sonhos dos futuros profissionais:

As novas tecnologias e o traço distintivo da "criatividade" da "inteligência" como identificador do campo publicitário movem o jovem para a busca de seus projetos, de seus desejos, de seus sonhos; ao passo em que a concorrência, as condições progressivamente precárias do trabalho assombram. Racionalidade e paixão fazem o estudante oscilar entre a euforia e o temor, entre a convicção e a dúvida. [...] ele alimenta expectativas de mudanças e se projeta como potencial transformador de realidades, às vezes a serviço do sistema no qual se insere como trabalhador explorado 
Eram os criativos publicitários artistas? Identidade, cotidiano e discurso.

de Maria Cristina Dias Alves

e simultaneamente feliz, em outras, como sujeito que vê a comunicação em compasso com a mudança dos consumidores e de um mundo melhor (CASAQUI, 2011: 71).

O profissional de comunicação está vivendo a transição de uma lógica produtiva a outra, como se refere Scolari (2008: 204), momento de grandes tensões e comparável ao Renascimento e à Revolução Industrial ${ }^{7}$.

Percebemos também que os novos suportes midiáticos podem alçar as agências de publicidade e propaganda à categoria de empresas de conteúdo, trabalhando em parceria com profissionais do cinema e da ficção televisiva como os episódios Super Nice $^{8}$, para o produto OMO líquido da Unilever, híbrido de publicidade e teledramaturgia, ou o seriado para a web do produto Ariel Líquido ${ }^{9}$ da Proctle \& Gamble.

A emergência do storytelling, conceito que ganha espaço por meio de diferentes manifestações, como branded entretainement, advertnement e vídeo viral, faz com que a publicidade ingresse no fenômeno da transmidialidade, no qual as narrativas desenrolam-se por meio de diferentes suportes midiáticos a fim de atingir nichos distintos, "alterando um pouco o tom do conteúdo de acordo com a mídia utilizada" (JENKINS, 2009: 138, 139).

A marca (ou produto) faz parte da narrativa, misturada à vida de protagonistas ou lugares, participa do desenrolar da história ou aparece em algumas cenas. Isso nos permite inferir que o trabalho dos redatores e diretores de arte tem se aproximado do dia a dia de profissionais de cinema e de TV. Como escreve Carrascoza, (2011: 8) dos anos de 1980 aos 2000, "a hibridização da linguagem publicitária incorpora elementos da narrativa ficcional em comerciais, projetos fílmicos”.

Sabemos que este foi um dos trabalhos dos criativos das agências desde sempre, uma vez que os comerciais tradicionais de televisão, ou mesmo anúncios, narram histórias e fazem parte dos textos culturais desde os primórdios da sociedade moderna.

Novamente são novas denominações para práticas antigas, estratégias discursivas que, ao classificar produtos e serviços das agências, e seus "modos de fazer”, buscam conformar novas normatizações.

\footnotetext{
${ }^{7}$ Tradução nossa

${ }^{8}$ Disponível em: <http://www.facebook.com/omobrasil?sk=app_130258690362927>. Acesso jun. 2011

${ }^{9}$ Disponível em: <http://www.descubraariel.com.br/pt_br/default.php>. Acesso jun. 2011.
} 
Eram os criativos publicitários artistas? Identidade, cotidiano e discurso.

de Maria Cristina Dias Alves

\section{CONSIDERAÇÕES FINAIS.}

Nossa hipótese é que o mundo do trabalho publicitário está em processo de mudança, com a convergência cada vez maior de saberes nas agências, principalmente entre os departamentos de criação e de planejamento, para dar conta da imprevisibilidade da interação com um consumidor mais disperso, propagador e produtor de narrativas.

[...] o consumidor do mundo moderno subverte a mensagem da propaganda. A prática do dia a dia possui uma liberdade gazeteira: nela, o mundo do movimento cotidiano se revela, como que numa descrição literária. Todo esse mundo é desprezado pelo 'expert', pelo especialista (BAIRON, 2008: 370).

Os criativos de publicidade atualmente estão às voltas com as demandas decorrentes dessa imprevisibilidade, buscando criar novos formatos de narrativas, mimetizando manifestações da arte, da televisão, do jornalismo, dos games, do amplo repertório cultural da sociedade, como sempre ocorreu. Contudo, com uma nova exigência, a da competência técnica, tanto no manejo dos meios digitais quanto das possibilidades de interação que as redes online oferecem.

Em 2012, o Brasil ganhou o seu primeiro Grand Prix de rádio em Cannes, ação criada pela agência Talent, para a revista GoOutside, na qual um sinal sonoro, transmitido durante a programação musical de fim de tarde rádio Band FM, tinha a propriedade de repelir mosquitos. ${ }^{10}$ Apenas uma pequena locução, nos intervalos da programação, informava que a Rádio Repelente de Mosquitos era patrocinada pela revista para que os leitores pudessem ficar livre de mosquitos. ${ }^{11}$

A peça vencedora é uma estratégia criativa que leva em conta a tecnologia na transmissão, já que o sinal sonoro, inaudível para os humanos, teve de ser inserido junto às músicas da programação. Ou seja, não é um spot ou jingle de rádio, formatos tradicionais tantas vezes criados pelas duplas das agências.

A alteração do nome do festival de Cannes, em 2011, para Festival Internacional de Criatividade, também reflete mudanças de modo a abarcar outras

\footnotetext{
${ }^{10}$ Disponível em: <http://www.youtube.com/watch?v=8YELawhjZeE>. Acesso em jun 2012.

${ }^{11}$ Disponível em: <http://www.youtube.com/watch?v=YYF63q3PgQw\&feature=related >. Acesso jun. 2012.
} 
Eram os criativos publicitários artistas? Identidade, cotidiano e discurso.

de Maria Cristina Dias Alves

maneiras de interação e de integração com o consumidor ${ }^{12}$ a fim de premiar diversos formatos.

Acreditamos que este é um momento de transição em que normatizações estão sendo revistas, procedimentos alterados. Olhar o dia a dia desses profissionais de perto, como propomos em nosso projeto de pesquisa, pode nos revelar caminhos norteadores sobre "modos de fazer" e os discursos que permeiam o cotidiano dos criativos e amalgamam identidades.

\section{REFERÊNCIAS BIBLIOGRÁFICAS.}

ALVES, M. C. D. Estamos em mudança: o trabalho dos criativos na publicidade contemporânea. In III Pró-Pesq PP - Encontro de Pesquisadores em Publicidade e Propaganda. ABP2 - Associação Brasileira de Pesquisadores em Publicidade, 2012 (no prelo).

BACCEGA, M. A. Palavra e Discurso, História e Literatura, São Paulo: Editora Ática, 2003. BACHELLARD, G. A formação do espírito científico. Rio de Janeiro: Contraponto, 1996.

BAIRON, S. Hipermídia: a margem digital e o cotidiano do consumidor. In PERES, C. BARBOSA, I (orgs.) Hiperpublicidade: atividades e tendências. São Paulo: Thomson Learning, 2008.

BARBOSA, I. P., TRINDADE, E. Enunciação publicitária e suas possibilidades. Acta Semiótica et Linguística. São Paulo: SBPL, v. 12, 2007.

BARBOSA, I. P. Propaganda e significação: do conceito à inscrição psicossocial. In CORRÊA, T. G. (org.). Comunicação para o mercado: instituições, mercado publicidade. São Paulo: Edicon,1995.

BARTHES, R. Mitologias. Rio de Janeiro: Difel, 1978.

BAUDRILLARD, J. O sistema dos objetos. São Paulo: Perspectiva, 1993.

BERTOMEU, J. V. C. Filmes publicitários: o processo de criação e as buscas do mercado global. Tese de doutorado em comunicação e semiótica, PUC, São Paulo, 2008.

\footnotetext{
${ }^{12}[\ldots .$.$] muitos dos Grand Prix são agora outorgados a experiências, tecnologias, mídia social,$ conteúdo gerado pelo usuário, serviços, eventos - as opções para os profissionais de marketing agora são as mais variadas e enriquecedoras, e precisamos abraçar estas mudanças". Disponível em <http://exame.abril.com.br/ marketing/noticias/cannes-agora-e- festival-de-criatividade>. Acesso jan. 2011.
} 
Eram os criativos publicitários artistas? Identidade, cotidiano e discurso.

de Maria Cristina Dias Alves

CARRASCOZA, J.A. E o vento mudou: as transformações do trabalho publicitário. In CASAQUI, V. et al. (orgs.). Trabalho e publicidade e propaganda: história, formação profissional, comunicação e imaginário. São Paulo: Atlas, 2011.

CARRASCOZA, J.A. Redação publicitária: estudos sobre a retórica do consumo. São Paulo: Futura, 2003.

CARREIRA, José C. Da estratégia do anunciante à comunicação publicitária: o caminho do significado.” In: PEREZ, C.; BARBOSA, I.S. (orgs.). Hiperpublicidade, Fundamentos e interfaces, v. 1. São Paulo: Thomson Learning, 2007.

CASAQUI, V. Publicidade imaginada: a visão dos estudantes sobre o mundo do trabalho publicitário. In CASAQUI, V. et al. (orgs.). Trabalho $e$ publicidade e propaganda: história, formação profissional, comunicação e imaginário. São Paulo: Atlas, 2011.

DE CERTEAU, M., GIARD L. e MAYOL, P. A invenção do cotidiano 2. Morar, cozinhar. Petrópolis: Ed Vozes, 1998.

DURRAFFOUURG, J. O trabalho e o ponto de vista da atividade. In SCHWARTZ, T., DURRIVE, L. (orgs.) Trabalho e ergologia; conversas sobre a atividade humana, cap. 2. Rio de Janeiro: Eduff, 2007.

FREDERICO, C. O consumo nas visões de Marx. In: BACCEGA, M. A. (org.). Comunicação e Consumo. São Paulo: Atlas, 2008

GOFFMAN, E. A representação do eu na vida cotidiana. Petrópolis: Vozes, 1985.

GRACIOSO, F., PENTEADO, J.R.W. 50 anos de vida e propaganda. São Paulo: Mauro Ivan Marketing Editorial, 2001.

HALL, S.; WOODWARD, K. Quem precisa de identidade? In: SILVA, T. T. (org.). Identidade e diferença: a perspectiva dos Estudos Culturais. Petrópolis: Vozes, 2000.

HALL, S. A centralidade da cultura: notas sobre as revoluções culturais do nosso tempo. $1997 . \quad$ Disponível em: <http://w3.ufsm.br/mundogeo/geopolitica/more/stuarthall.html>. Acesso em maio de 2010.

HARVEY, D. Espaços de esperança. São Paulo: Ed. Loyola, 2004. HELLER, A. O cotidiano e a história. São Paulo: Paz e Terra, 2008.

IANNI, O. Enigmas da modernidade mundo. Rio de Janeiro: Civilização Brasileira, 
Eram os criativos publicitários artistas? Identidade, cotidiano e discurso.

de Maria Cristina Dias Alves

2003. JENKINS, H. Cultura da convergência. 2a . ed., São Paulo: Aleph, 2009.

MARCONDES, P. Uma história da propaganda brasileira. São Paulo, Ediouro, 2001.

MARQUES DE MELO, J. ECA, antes e depois da propaganda. In AQUINO, V. (org.).

A USP e a invenção da propaganda: 40 anos depois. São Paulo: FUNDAC, 2010.

PIRATININGA, C. Publicidade: arte ou artifício? São Paulo: T. A. Queiroz, 1985.

ROCHA, E. P. G. Magia e capitalismo: um estudo antropológico da publicidade. São Paulo: Brasiliense, 1985.

SANTARELLI, C. P .G. Processos de análise da imagem gráfica: um estudo comparativo da publicidade de moda. Tese de Doutorado, 2009, ECA, Universidade de São Paulo.

SANTOS, G. F. C. Agência de propaganda: casa de Orates ou templo do Oráculo. In Revista Signos do Consumo, vol. 2, n 2. São Paulo: ECA- USP, 2009.

SCOLARI, C. Hipermediaciones: elementos para una teoría de la comunicación digital interactiva. Barcelona: Gedisa, 2008.

TRINDADE. E. Recepção publicitária e práticas de consumo. In Revista Fronteiras - estudos midiáticos , X (2): 73-80, mai/ago 2008.

FIGURAS

Figura 1 - Disponível em:

<http://www.facebook.com/photo.php?fbid=10151053109641579\&set=a.48620446157

8.296484.310719156578\&type=1\&theater $>$. Acesso jun. 2012.

Artigo submetido: outubro de 2012

Artigo aprovado: dezembro de 2012 